\title{
UPAYA MENINGKATKAN MINAT BELAJAR DAN KEMAMPUAN PEMECAHAN MASALAH MATEMATIS MELALUI MODEL QUICK ON THE DRAW
}

\author{
MONICA KHOIRUNNISA \\ Universitas Indraprasta PGRI, MTs Nurul Falah Kosambi \\ e-mail : id.monicakhoirunnisa@gmail.com
}

\begin{abstract}
ABSTRAK
Penelitian ini merupakan Penelitian Tindakan Kelas dengan dua teknik analisis, yaitu analisis kualitatif dan analisis statistik deskriptif untuk menganalisis minat belajar dan kemampuan pemecahan masalah matematis siswa. Minat belajar merupakan ketertarikan individu dalam suatu proses yang menghasilkan perubahan tingkah laku, sedangkan, kemampuan pemecahan masalah matematis adalah kemampuan untuk dapat menyelesaikan pertanyaan-pertanyaan atau masalah dalam kehidupan sehari-hari. Model quick on the draw merupakan suatu pembelajaran untuk menguasai konsep-konsep materi yang dapat meningkatkan antusiasme dan semangat siswa dalam belajar karena adanya suatu kerja tim dan kecepatan melalui adanya kartu soal dan set pertanyaan. Berdasarkan hasil penelitian dan pembahasan, diketahui jika model quick on the draw dapat meningkatkan minat belajar dan kemampuan pemecahan masalah matematis dengan dua siklus. Hasil rata - rata prosentase lembar observasi aktivitas guru meningkat sebesar 16,18\% yang pada siklus I sebesar 75,98\% menjadi 92,16\% di siklus II. Kemudian, hasil rata - rata prosentase lembar observasi aktivitas siswa mengalami peningkatan sebesar $19,12 \%$ yang awalnya $72,55 \%$ di siklus I menjadi $91,67 \%$ di siklus II. Selain itu, kemampuan pemecahan masalahnya juga meningkat $26,54 \%$ dari $40,88 \%$ di siklus I menjadi $67,42 \%$ di siklus II.
\end{abstract}

Kata Kunci: Minat Belajar, Kemampuan Pemecahan Masalah, Model Quick On The Draw

\section{ABSTRACT}

This research is a Classroom Action Research with two analytical techniques, namely qualitative analysis and descriptive statistical analysis to analyze students' interest in learning and mathematical problem solving abilities. Interest in learning is an individual's interest in a process that produces changes in behavior, meanwhile, mathematical problem solving ability is the ability to be able to solve questions or problems in everyday life. The quick on the draw model is a learning to master material concepts that can increase students' enthusiasm and enthusiasm in learning because of teamwork and speed through question cards and question sets. Based on the results of research and discussion, it is known that the quick on the draw model can increase learning interest and mathematical problem solving ability with two cycles. The results of the average percentage of teacher activity observation sheets increased by $16.18 \%$ which in the first cycle was $75.98 \%$ to $92.16 \%$ in the second cycle. Then, the results of the average percentage of student activity observation sheets increased by $19.12 \%$ from $72.55 \%$ in the first cycle to $91.67 \%$ in the second cycle. In addition, the problem solving ability also increased by $26.54 \%$ from $40.88 \%$ in the first cycle to $67.42 \%$ in the second cycle.

Keywords: Learning Interest, Problem Solving Ability, Quick On The Draw Model

\section{PENDAHULUAN}

Di tingkat SMP/MTs, matematika menjadi salah satu mata pelajaran yang selalu ada di setiap kurikulum. Mata pelajaran matematika perlu diberikan kepada siswa untuk membekali mereka kemampuan berpikir logis, kritis, sistematis, kreatif, dan bekerja sama dalam menghadapi persoalan. Namun, sampai saat ini mata pelajaran matematika menjadi salah satu mata pelajaran yang kurang disukai, bahkan paling ditakuti sehingga menurunkan minat siswa dalam belajar.

Pembelajaran matematika dapat dikatakan bermakna apabila dapat menumbuhkan minat belajar siswa. Dengan adanya minat untuk belajar dalam diri siswa akan mempermudah 
guru dalam mencapai tujuan pembelajaran. Karena minat untuk belajar dapat membuat siswa belajar dengan sebaik mungkin, sehingga dapat menambah kegiatan belajar. Ia tidak segan untuk belajar karena bahan belajar terlihat menarik, mudah dipelajari, dan mudah disimpan dalam ingatan.

Dalam salah satu Jurnal Studi Sosial, Budiwibowo mengatakan jika minat belajar adalah salah satu keberhasilan anak dalam belajar. Minat memiliki peranan dan dampak yang penting dalam sikap dan perilaku. Seorang siswa yang memiliki minat dalam kegiatan pembelajaran akan lebih giat dan rajin belajar daripada siswa yang kurang berminat dalam belajar (2016:61). Dari pemaparan tersebut, terjadi ketimpangan dengan realitas observasi yang dilakukan oleh peneliti. Berdasarkan observasi di MTs Nurul Falah Kosambi, khususnya di kelas 7, banyak siswa terlihat kurang memusatkan perhatian dalam proses pembelajaran. Hal ini terlihat dari siswa yang kurang antusias ketika guru memasuki kelas. Banyak anak yang baru menyiapkan alat tulis dan bahan belajar ketika guru memberikan perintah. Hal ini terjadi berulang-ulang dari dua semester sebelumnya dan tentunya terus berimbas pada minat belajar siswa. Berdasarkan observasi tersebut, jelas bahwa minat belajar siswa di kelas 7 MTs Nurul Falah Kosambi sangatlah kurang.

Keberhasilan belajar dapat dilihat dari hasil belajar siswa. Hasil belajar tersebut dapat berupa kemampuan - kemampuan yang dimiliki anak setelah melakukan proses pembelajaran. Salah satu kemampuan yang penting dimiliki oleh siswa dalam pembelajaran matematika adalah kemampuan pemecahan masalah matematis. Effendi (2012:3) mengatakan bahwa siswa harus memiliki kemampuan pemecahan masalah untuk melatih siswa menghadapi berbagai permasalahan yang semakin kompleks. Masalah tersebut bisa berupa masalah matematika, masalah di bidang studi lain, atau bahkan permasalahan yang dijumpainya sehari - hari. Oleh sebab itu, kemampuan siswa untuk memecahkan masalah matematis harus selalu dilatih agar siswa dapat menyelesaikan permasalahan yang dihadapi.

Akan tetapi, pada hasil belajar Matematika pada Penilaian Tengah Semester (PTS) Ganjil tahun ajaran 2017/2018 di kelas 7A menunjukkan bahwa hanya 5 siswa dari 24 siswa yang mencapai nilai Kriteria Ketuntasan Minimal (KKM), artinya ada 20,83\% siswa yang mencapai nilai KKM, yakni 70. Hal ini juga sering terulang pada nilai tugas, yakni siswa yang mendapat nilai di atas 70 tidak lebih dari setengah jumlah siswa dalam kelas 7A. Beberapa hal tersebut menunjukkan bahwa kemampuan pemecahan masalah matematis siswa kelas 7 di MTs Nurul Falah Kosambi masih sangat kurang.

Berdasarkan kenyataan - kenyataan tersebut, terlihat jelas ketimpangan antara teori dan praktik dilapangan. Mengingat pentingnya minat belajar dan kemampuan pemecahan masalah bagi siswa, maka perlunya solusi untuk meningkatkan minat belajar dan kemampuan pemecahan masalah matematis siswa. Untuk mengatasinya, perlu dilakukan perubahan model pembelajaran yang dapat meningkatkan minat belajar dan kemampuan pemecahan masalah matematis siswa, salah satunya model pembelajaran kooperatif.

Wandira, Asih, dkk (2017:4) menuliskan bahwa model kooperatif merupakan strategi belajar yang mengharuskan siswa berkelompok untuk saling bekerja sama dalam kelompoknya sehingga siswa lebih mudah memahami dan memecahkan masalah dengan berdiskusi. Pembelajaran kooperatif juga mendorong siswa untuk lebih aktif dalam bertanya dan berpendapat. Dengan demikian, siswa akan lebih antusias dalam belajar sehingga minat belajarnya meningkat, dan melalui diskusi dapat mengembangkan pula kemampuan pemecahan masalah matematisnya. Adapun salah satu model pembelajaran kooperatif untuk meningkatkan minat sekaligus kemampuan pemecahan masalah matematis yang dapat digunakan adalah model quick on the draw.

Menurut Lestiyaningsih, Hobri, dkk (2013: 40) pembelajaran Quick on the Draw mengedepankan aktivitas kerja sama siswa dalam kelompok kecil yang bertujuan untuk menjadi kelompok pemenang dalam menyelesaikan set pertanyaan. Siswa dituntut aktif dalam kelompok untuk menyelesaikan permasalahan dan kemudian melaporkan hasil diskusi yang terkonsep seperti permainan. Pendapat ini sesuai dengan penelitian karena dengan adanya 
konsep permainan dapat meningkatkan minat belajar siswa. Selain itu, kemampuan pemecahan masalah matematis siswa akan meningkat melalui permasalahan - permasalahan yang diberikan dalam set pertanyaan. Berdasarkan beberapa uraian tersebut, dapat dikatakan bahwa model quick on the draw diperkirakan dapat meningkatkan minat belajar dan kemampuan pemecahan masalah matematis siswa di kelas 7 MTs Nurul Falah Kosambi.

\section{METODE PENELITIAN}

Penelitian ini merupakan Penelitian Tindakan Kelas (PTK). Arikunto mengatakan bahwa PTK digunakan untuk para guru yang ingin meningkatkan kualitas pembelajarannya melalui pemberian tindakan kepada siswa sebagai objek di dalam kelas (2015:3). Suhardjono (2015:143-144) mengatakan bahwa setiap tindakan PTK terdiri dari empat kegiatan yaitu perencanaan, tindakan, pengamata, serta evaluasi dan refleksi. Penelitian tindakan kelas ini dilaksanakan dengan siklus, yang di setiap siklusnya terdapat 3 pertemuan dan 4 tahapan. Empat tahapan dalam penelitian tindakan kelas ini, yaitu: (1) perencanaan; (2) tindakan; (3) pengamatan; dan (4) refleksi.

Penelitian ini dilaksanakan di MTs Nurul Falah Kosambi dengan subjek penelitian kelas 7 yang terdiri dari 43 siswa yaitu 26 siswa laki - laki, dan 17 siswa perempuan. Instrumen penelitian yang digunakan untuk mengumpulkan data penelitian ini yaitu tes, observasi, dokumentasi, dan catatan lapangan. Dalam penelitian tindakan kelas ini, peneliti menggunakan dua jenis teknik analisis data, yaitu analisis kualitatif dan analisis dengan statistik deskriptif presentase.

Analisis kualitatif digunakan untuk menganalisis hasil lembar observasi dan catatan lapangan. Analisis dilakukan dengan memberikan predikat (baik atau buruk, tinggi atau rendah) dari rata - rata prosentase dari setiap siklus. Sedangkan analisis statistik deskriptif digunakan untuk menganalisis hasil tes soal pilihan ganda. Analisis dilakukan dengan menghitung rata rata peningkatan dari setiap siklus.

\section{HASIL DAN PEMBAHASAN}

Indikator keberhasilan dalam penelitian tindakan kelas ini adalah meningkatnya minat belajar siswa minimal $80 \%$ dari perhitungan skor lembar observasi, dan meningkatnya kemampuan pemecahan masalah matematis siswa memiliki prosentase analisis indikator kemampuan pemecahan masalah minimal mencapai 60\%. Berdasarkan hasil pelaksanaan siklus, penelitian tindakan kelas ini berhasil dengan dua siklus.

\section{Hasil}

Kondisi awal penelitian dilihat peneliti melalui nilai tugas mandiri yang berisikan 4 soal kemampuan pemecahan masalah. Adapun hasil prosentase pencapaian indikator pemecahan masalah diperoleh sebesar 26,16\%.

\section{1) Siklus I}

\section{a. Deskripsi Pelaksanaan Tindakan Siklus I}

Penelitian pada siklus I terdiri dari 4 pertemuan. Pertemuan ke-1 sampai dengan ke-3 digunakan untuk menerapkan model Quick on The Draw dalam pembelajaran Matematika. Kemudian, pertemuan ke-4 digunakan untuk melaksanakan tes Siklus I.

Hasil observasi pada siklus I pada setiap pertemuannya mengalami perubahan. Perubahan keseluruhan dari hasil observasi yang dilakukan pada siklus I dapat dilihat pada gambar grafik berikut : 


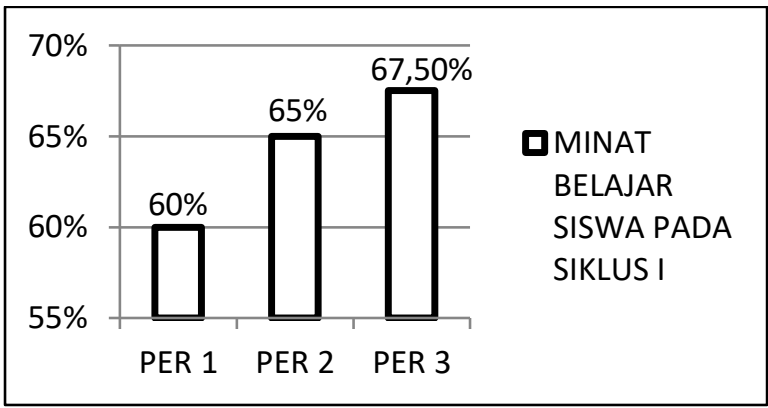

Gambar 1. Diagram Prosentase Minat Belajar Siswa pada Siklus I

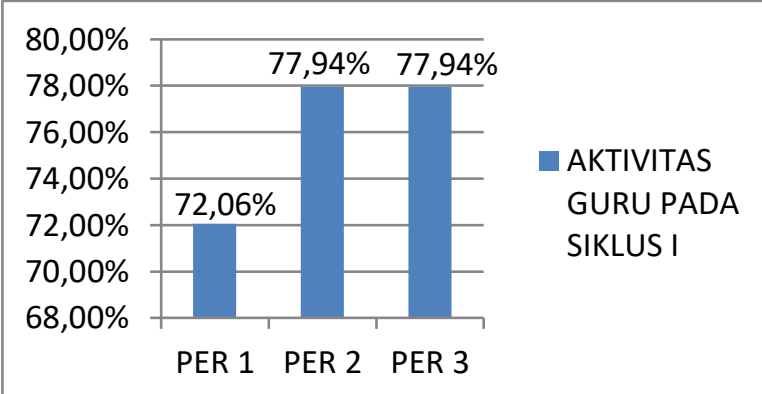

Gambar 2. Diagram Prosentase Aktivitas Guru pada Siklus I

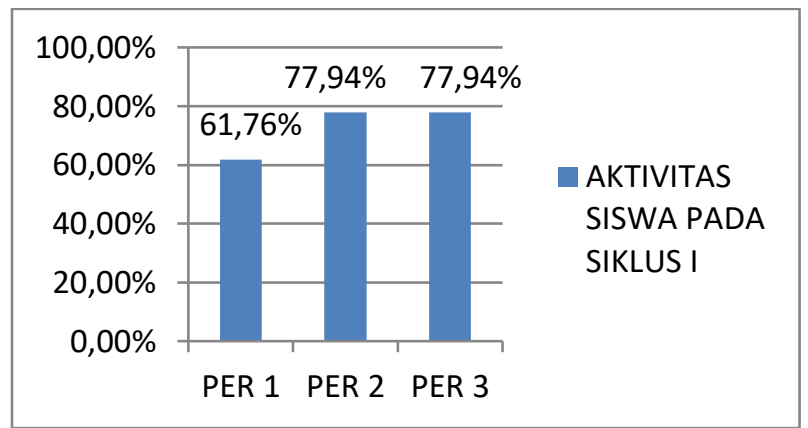

\section{Gambar 3. Diagram Prosentase Aktivitas Siswa pada Siklus I}

Untuk catatan lapangan pada Siklus I diperoleh data sekitar 6,98\% siswa tidak hadir, ada $23,25 \%$ siswa gaduh, dan $30,23 \%$ siswa pasif yang tercatat selama pertemuan 1 sampai 3. Adapun hasil identifikasi kemampuan pemecahan masalah pada Siklus I dapat dilihat pada tabel berikut :

\section{Tabel 1. Prosentase Pencapaian Indikator Kemampuan} Pemecahan Masalah Matematis Siklus I

\begin{tabular}{|l|c|}
\hline \multicolumn{1}{|c|}{ Indikator } & Prosentase \\
\hline $\begin{array}{l}\text { A. Siswa mampu mengidentifikasi dan memahami } \\
\text { rumusan masalah. }\end{array}$ & 60 \\
\hline $\begin{array}{l}\text { B. Siswa mampu membuat dan menentukan rencana atau } \\
\text { strategi pemecahan masalah dari hasil identifikasi dan } \\
\text { rumusan masalah. }\end{array}$ & 44,88 \\
\hline $\begin{array}{l}\text { C. Siswa mampu menerapkan rencana atau strategi } \\
\text { pemecahan masalah. }\end{array}$ & 29,68 \\
\hline D. Siswa mampu menjelaskan hasil pemecahan masalah. & 28,94 \\
\hline $\begin{array}{c}\text { Rata - Rata Prosentase Kemampuan Pemecahan } \\
\text { Masalah }\end{array}$ & $\mathbf{4 0 , 8 8}$ \\
\hline
\end{tabular}




\section{b. Refleksi Pembelajaran Siklus I}

Refleksi didasarkan pada proses pelaksanaan pembelajaran dan hasil observasi yang sudah dilakukan pada siklus I. Selama pelaksanaan siklus I dapat diidentifikasi beberapa permasalahan, diantaranya : (1) masih banyak siswa yang membuat gaduh, (2) masih banyak siswa yang pasif dalam pembelajaran, (3) masih ada beberapa siswa yang kurang fokus dalam mendengarkan penjelasan guru dan memilih bertanya dengan teman jika mengalami kesulitan, (5) yang menjadi pemenang dari pertemuan 1 sampai 3 adalah kelompok yang sama.

\section{2) Siklus II}

\section{a. Deskripsi Pelaksanaan Tindakan Siklus II}

Perencanaan tindakan siklus II hampir sama dengan siklus I dengan memperhatikan hasil refleksi dari siklus I sehingga permasalahan - permasalahan yang ada pada siklus I diperbaiki di siklus II. Adapun solusi yang diterapkan adalah penerapan aturan baru dalam pembentukan kelompok dan bagi kelompok yang menjadi pemenang tetap pada Siklus I, agar menyebar di berbagai kelompok. Seperti siklus I, ada 4 pertemuan pada siklus II, yakni 3 kali pertemuan penerapan model quick on the draw dan 1 pertemuan dilakukan evaluasi.

Berdasarkan hasil observasi, perubahan keseluruhan dari hasil observasi yang dilakukan pada siklus II disajikan pada gambar grafik berikut :

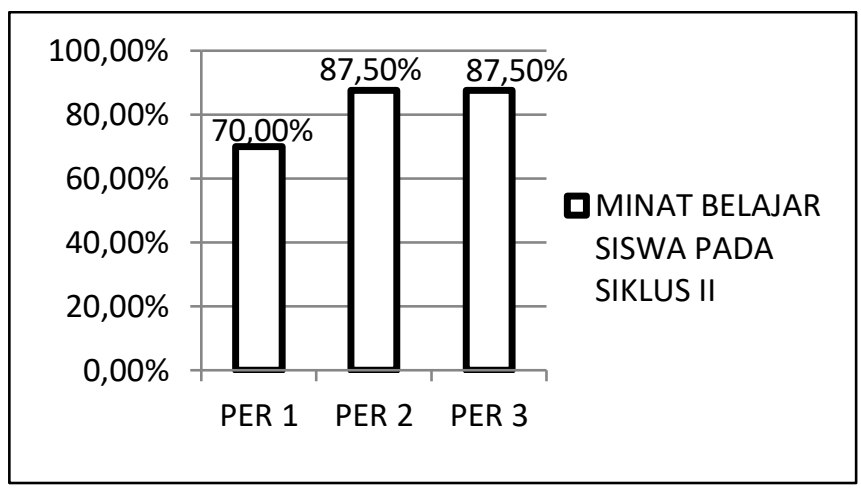

\section{Gambar 4. Prosentase Minat Belajar Siswa pada Siklus II}

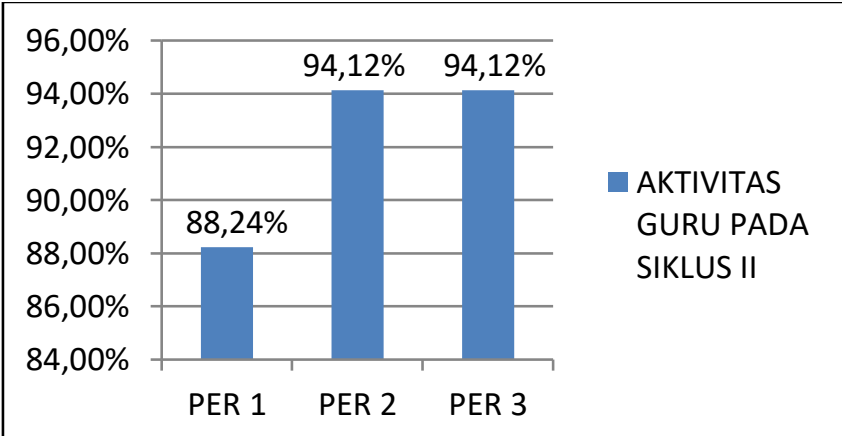

Gambar 5. Prosentase Aktivitas Guru pada Siklus II

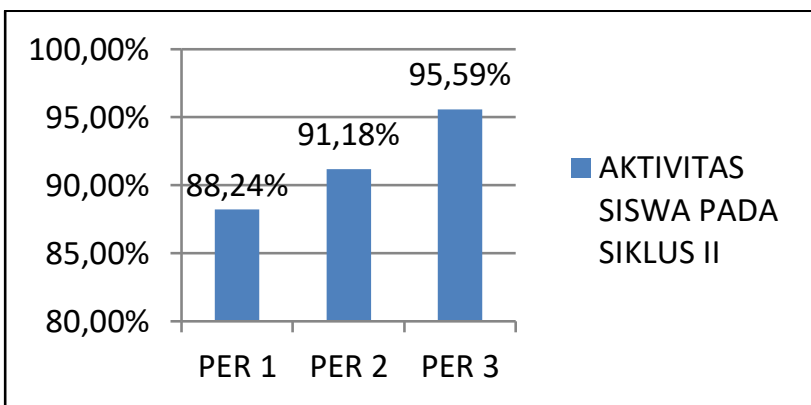

Gambar 5. Prosentase Aktivitas Siswa pada Siklus II 
Untuk catatan lapangan pada Siklus II diperoleh data sekitar 4,65\% siswa tidak hadir, ada $6,97 \%$ siswa gaduh, dan $4,65 \%$ siswa pasif yang tercatat selama pertemuan 1 sampai 3. Adapun hasil identifikasi kemampuan pemecahan masalah pada Siklus II dapat dilihat pada tabel berikut :

Tabel 2. Prosentase Pencapaian Indikator Kemampuan Pemecahan Masalah Matematis Siklus II

\begin{tabular}{|c|c|}
\hline Indikator & Prosentase \\
\hline $\begin{array}{l}\text { A. Siswa mampu mengidentifikasi dan memahami } \\
\text { rumusan masalah. }\end{array}$ & 73,49 \\
\hline $\begin{array}{l}\text { B. Siswa mampu membuat dan menentukan rencana atau } \\
\text { strategi pemecahan masalah dari hasil identifikasi dan } \\
\text { rumusan masalah. }\end{array}$ & 64,19 \\
\hline $\begin{array}{l}\text { C. Siswa mampu menerapkan rencana atau strategi } \\
\text { pemecahan masalah. }\end{array}$ & 67,85 \\
\hline D. Siswa mampu menjelaskan hasil pemecahan masalah. & 64,15 \\
\hline $\begin{array}{c}\text { Rata - Rata Prosentase Kemampuan Pemecahan } \\
\text { Masalah }\end{array}$ & 67,42 \\
\hline
\end{tabular}

\section{b. Refleksi Pembelajaran Siklus II}

Refleksi di siklus II mengacu pada hasil penelitian dan indikator keberhasilan. Setelah melakukan pembelajaran matematika dengan model quick on the draw ditemukan peningkatan minat belajar dan kemampuan pemecahan masalah siswa. Berdasarkan data, terlihat adanya peningkatan yang baik pada minat belajar siswa, kinerja guru, aktivitas siswa, dan hasil belajar siswa yang dianalisis sesuai indikator kemampuan pemecahan masalah siswa. Pada Siklus II, analisis minat belajar siswa menunjukkan prosentase 81,67\%, aktivitas guru 92,16\%, dan aktivitas siswa 91,67\%. Selain itu, hasil analisis kemampuan pemecahan masalah siswa menjadi $67,42 \%$. Karena indikator keberhasilan telah tercapai, maka penelitian ini tidak dilanjutkan di siklus berikutnya.

\section{Pembahasan}

Pada penelitian tindakan kelas ini, pembelajaran dilakukan dengan menerapkan model pembelajaran quick on the draw untuk meningkatkan minat belajar siswa dan kemampuan pemecahan masalah matematis siswa di Kelas 7 MTs Nurul Falah Kosambi. Kegiatan quick on the draw bernuansa perlombaan membangkitkan antusias dan semangat siswa dalam mengikuti pembelajaran. Dalam mengerjakan kartu soal, siswa juga saling berdiskusi dengan teman teman kelompoknya. Walaupun siswa menghadapi soal yang cukup sulit, siswa saling memberikan pendapatnya di dalam kelompok, kemudian guru juga dapat memberikan sedikit bantuan kepada kelompok yang mengalami kesulitan (Suryadinata, 2015:15). Pengaplikasian quick on the draw pada bidang matematika, yakni adanya kartu soal atau kartu permasalahan yang memuat suatu langkah penyelesaian masalah matematika agar siswa terlatih untuk meneliti kebenaran dari setiap langkah penyelesaian sebelum melangkah ke langkah berikutnya (Ginnis, 2016:164).

Dari hasil analisis data observasi terhadap minat belajar, aktivitas guru, dan aktivitas siswa dalam proses pembelajaran Siklus I sampai Siklus II diketahui bahwa proses pembelajaran mengalami peningkatan yang ditunjukkan oleh adanya peningkatan rata - rata prosentase pengamatan. Pada Siklus I rata - rata hasil pengamatan minat belajar siswa sebesar $64,17 \%$, dan meningkat pada Siklus II menjadi 81,67\%. Peningkatan minat belajar dengan 
pembelajaran quick on the draw ini juga sejalan dengan penelitian yang dilakukan oleh Pamilih (2014) yang menyimpulkan bahwa penerapan strategi pembelajaran quick on the draw dapat meningkatkan minat belajar IPS peserta didik kelas V SD Negeri 01 Wonolopo. Hal ini ditunjukkan pada hasil observasi minat belajar IPS, peserta didik yang berminat tinggi pada Prasiklus sebesar 17\% meningkat menjadi 30\% Pada Siklus I dan pada hasil siklus II meningkat menjadi $87 \%$.

Pembelajaran quick on the draw dapat meningkatkan aktivitas siswa dengan terlibat secara aktif dalam proses pembelajaran yang diharuskan menguasai konsep-konsep materi yang sedang dipelajari baik secara individu maupun dalam diskusi kelompoknya (Safitri, 2016:48). Pendapat ini sejalan dengan hasil pengamatan pada aktivitas guru dan siswa pada Siklus I sampai Siklus II juga mengalami peningkatan. Pada Siklus I rata - rata hasil pengamatan aktivitas guru sebesar 75,98\%, dan meningkat pada Siklus II menjadi 92,16\%. Kemudian pada rata - rata hasil pengamatan aktivitas siswa pada Siklus I sebesar 72,55\%, dan meningkat pada Siklus II menjadi 91,67\%.

Pemecahan masalah matematis merupakan suatu aktivitas berpikir yang rumit dan menyeluruh sebagai proses untuk mengatasi suatu masalah dan pemecahannya memerlukan beberapa strategi (Fadillah, 2009:M-554). Berdasarkan analisis data, pencapaian kemampuan pemecahan masalah matematis siswa pada Siklus I mengalami peningkatan di Siklus II. Hasil rata-rata pencapaian kemampuan pemecahan masalah matematis siswa pada Siklus I sebesar 40,88\%, dan meningkat pada Siklus II menjadi 67,42\%.

\section{KESIMPULAN}

Berdasarkan hasil penelitian tindakan kelas ini, dapat disimpulkan bahwa model quick on the draw dapat meningkatkan minat belajar dan kemampuan pemecahan masalah matematis siswa di kelas 7 MTs Nurul Falah Kosambi. Minat belajar dan kemampuan pemecahan masalah matematis siswa meningkat setelah penerapan langkah - langkah model quick on the draw dalam proses pembelajaran. Dengan adanya kelompok - kelompok diskusi dan hampir serupa dengan permainan, minat belajar siswa meningkat dan kemampuan pemecahan masalah matematisnya meningkat melalui set soal yang diberikan. Hal tersebut dapat dilihat melalui hasil observasi pada setiap siklusnya.

Keberhasilan peningkatan minat belajar siswa dapat dilihat dari keberhasilan indikator minat belajar yakni perhitungan skor lembar observasi $\geq 80 \%$. Hasil lembar observasi minat belajar siswa mengalami peningkatan sebesar 17,5\% yang awal rata - rata prosentase lembar observasi minat belajar siswa di siklus I sebesar $64,17 \%$ menjadi $81,67 \%$ pada siklus II. Adapun untuk hasil lembar observasi aktivitas guru meningkat sebesar 16,18\% di mana awal rata - rata prosentasenya pada siklus I sebesar 75,98\% menjadi 92,16\% di siklus II. Kemudian, hasil lembar observasi aktivitas siswa mengalami peningkatan sebesar 19,12\% yang awal rata - rata prosentasenya 72,55\% di siklus I menjadi 91,67\% di siklus II. Selain itu, keberhasilan peningkatan kemampuan pemecahan masalah matematis terlihat dari hasil analisis pencapaian indikator yang $\geq 80 \%$. Hasil analisis pencapaian indikator kemampuan pemecahan masalah meningkat $26,54 \%$ dari $40,88 \%$ di siklus I menjadi $67,42 \%$ di siklus II.

\section{DAFTAR PUSTAKA}

Arikunto, S,. Suhardjono, \& Supardi. (2015). Penelitian Tindakan Kelas. Jakarta: PT Bumi Aksara.

Budiwibowo, S. (2016). "Hubungan Minat Belajar Siswa dengan Hasil Belajar IPS di SMP Negeri 14 Kota Madiun.” Gulawentah: Jurnal Studi Sosial Universitas PGRI Madiun 1(1): 60-68.

http://e-journal.unipma.ac.id/index.php/gulawentah/article/download/66/60 (diakses 18 Januari 2018)

Effendi, L.A. (2012). "Pembelajaran Matematika dengan Metode Penemuan Terbimbing untuk Meningkatkan Kemampuan Representasi dan Pemecahan Masalah Matematis Siswa 
SMP.” Jurnal Penelitian Pendidikan Universitas Pendidikan Indonesia 13(2): 1-10. http://jurnal.upi.edu/file/Leo_Adhar.pdf (diakses 16 Januari 2018)

Fadillah, S. (2009). Seminar Nasional Penelitian, Pendidikan, dan Penerapan MIPA dengan Tema Revitalisasi MIPA dan Pendidikan MIPA Dalam Rangka Penguatan Kapasitas Kelembagaan dan Profesionalisme Menuju World Class University, Yogyakarta, 16 Mei.

Ginnis, P. (2016). Trik \& Taktik Mengajar Strategi Meningkatkan Pencapaian Pengajaran di Kelas. Jakarta: PT Indeks.

Lestiyaningsih, H., Hobri, \& Indah, A. (2013). "Penerapan Pembelajaran Quick On The Draw untuk Meningkatkan Hasil Belajar Matematika pada Sub Pokok Bahasan Aritmetika Sosial Siswa Kelas VII F Semester Ganjil SMP Negeri 10 Jember Tahun Ajaran 2012/2013." Kadikma Universitas Jember 4(2): 39-48 . https://jurnal.unej.ac.id/index.php/kadikma/article/download/1037/835/ (diakses 18 Januari 2018)

Pamilih, R.D. (2014). Naskah Publikasi Skripsi. Februari, 2014. Universitas Muhammadiyah Surakarta, Program Studi Pendidikan Guru Sekolah Dasar Fakultas Keguruan dan Ilmu Pendidikan. diakses dari http://eprints.ums.ac.id/27923/16/NASKAH_PUBLIKASI_SKRIPSI.pdf

Safitri, P.T. (2016). "Pembelajaran Quick On The Draw untuk Meningkatkan Kemampuan Penalaran Matematis Siswa Sekolah Menengah Pertama." Jurnal Prima Universitas Muhammadiyah Tangerang 5(2): 47-53.

https://jurnal.umt.ac.id/index.php/prima/article/download/194/137 (diakses 18 Januari 2018)

Suryadinata, N. (2015). "Penerapan Pembelajaran Quick On The Draw Menggunakan Masalah Open Ended terhadap Kemampuan Berpikir Kreatif Matematis Siswa SMP." Edumatica Universitas Jambi 5(2): 9-18.

https://online-journal.unja.ac.id/index.php/edumatica/article/view/2925 (diakses 04 Mei 2018)

Wandira, S.M.A., V.Y., I.A \& Pamungkas, A.S. (2017). "Efektivitas Model Pembelajaran Kooperatif Tipe Think Pair Share dan The Power Of Two Ditinjau dari Kemampuan Pemecahan Masalah Matematis." Prima: Jurnal Pendidikan Matematika Universitas Muhammadiyah Tangerang 1(1): 1-18.

https://jurnal.umt.ac.id/index.php/prima/article/download/250/168 (diakses 02 Februari 2018) 